\title{
Improvement of Nutritional Values of Agaricus Bisporus Mushroom Stalk and Cap through Solid-State Fermentation Using Aspergillus niger
}

\author{
Aydın Altop ${ }^{1, a, *}$ \\ ${ }^{I}$ Department of Animal Science, Faculty of Agriculture, Ondokuz Mayls University, 55270 Samsun, Turkey \\ ${ }^{*}$ Corresponding author

\begin{tabular}{|c|c|}
\hline A R T I C LE INFO & A B S T R A C T \\
\hline $\begin{array}{l}\text { Received : 02/08/2019 } \\
\text { Accepted : 16/08/2019 }\end{array}$ & $\begin{array}{l}\text { This study aimed to investigate the effect of solid-state fermentation on the nutritional composition } \\
\text { of Agaricus bisporus mushroom stalk and cap. Four homogenous test samples were prepared from } \\
\text { the fermented mushroom stalk (Fermented MS), unfermented mushroom stalk (MS), fermented } \\
\text { mushroom cap (Fermented MC), and unfermented mushroom cap (MC); each was independently } \\
\text { analyzed in triplicates, providing a total of } 12 \text { independent measurements of all treatments. } \\
\text { Nutritional changes in the mushrooms were determined by analyzing crude protein (CP), ether } \\
\text { extract (EE), crude ash (CA), crude fiber (CF), hemicellulose, neutral detergent fiber (NDF), acid } \\
\text { detergent lignin (ADL), and acid detergent fiber (ADF) contents. The best improvement in } \\
\text { nutritional composition was obtained from the MS with increasing the crude protein ( } 35 \% \text { ). The } \\
\text { results related to other parameters are similar among all the treatments, except for CF. To conclude, } \\
\text { the fermented MS can be considered as an alternative protein resource in animal nutrition. }\end{array}$ \\
\hline
\end{tabular}

Fermentation

Animal nutrition

Waste product

(c) $($ ) $(9)$ This work is licensed under Creative Commons Attribution 4.0 International License

\section{Introduction}

For centuries, people have used natural resources like plants, minerals, and animal products in treatment and prevention of many diseases of themselves and their animals. Mushroom is one of the natural resources that used as medicines or functional food on the world. Because they have beneficial effects on health, such as antibacterial, antifungal, anti-oxidant, hypoglycemic activities (Wang and $\mathrm{Ng}, 1999$ ) and produced some protein such as lectins (Wang et al. 2002), ribosome-inactivating proteins, antifungal proteins (Lam and $\mathrm{Ng}$, 2001) and rib nucleases (Kobayashi et al. 1992).

Mushroom production has been rapidly raised in Turkey about more than 40.712 tons and in the world more than 10 million tons annually (TUIK, 2017). Mushrooms are an ideal food for people due to the high content of fiber and protein or low content of fat (Wong et al. 2003). Therefore, edible mushrooms have the important potential in filling the nutritional gap in human nutrition. On the other hand, it would be difficult to say that mushrooms are quite cheap feedstuff for animal nutrition in the world, except for by-products of mushrooms such as stalk, the surplus of need, near to shelf life of mushroom, etc. Although there have been so many studies which were reported the effects of mushrooms powder (intact form) or extracts on performance, immune traits, meat quality, gastrointestinal traits in broilers, laying hens or pigs (Guo et al., 2004a; Guo et al., 2004b; Giannenas et al., 2010a; Giannenas et al., 2010b), there has been limited studies about the basic chemical composition, the nutrient digestibility, the metabolizable energy content of mushroom stalk meal or cap. For example, Buwjoom et al., (2004) reported that there was difference between stalk meal and cap of L. edodes in terms of crude protein (CP), ether extract (EE), crude fiber, gross energy, calcium, and phosphorus contents, and L. edodes stalk meal could be used as an alternative feedstuff for poultry. Lee et al., (2005) suggested that if these by-products were evaluated in animal feeds and feed additives or any field, they would cause environmental pollution such as a bad odor in the future. 
Recently, solid-state fermentation has been considered as a useful and inexpensive method to improve the nutritional composition of feedstuffs and to eliminate its antinutritional factors. Indeed, improvement of both protein quantity and quality (Mathivanan et al., 2006; Zhang et al., 2012), degradation of non-starch polysaccharides to monosaccharides such as glucose and eliminating of possible antinutritional factors (Zhao et al., 2013 ) in feedstuffs or agricultural residues. However, there has been limited information about the nutrient values or zootechnical performance traits of fermented mushrooms stalk or cap (Chu et al., 2012). Furthermore, there is no report about the nutrient composition of fermented $A$. bisporus stalk or cap. In light of all the above information, the study was conducted to determine whether mushrooms stalk and cap is suitable for SSF and the changes in their nutrient composition.

\section{Materials and Methods}

\section{Preparation of A. bisporus}

Mushrooms (A. bisporus) were obtained from a local mushroom producer (Samsun, Turkey) and the intact mushrooms were divided into two parts as stalk and cap before drying. Then, each part of mushrooms was sundried for three days to a stable moisture content of about $10-20 \%$ and the soils attached to mushroom stalk were removed. Samples were oven-dried at $60-70^{\circ} \mathrm{C}$ for $48 \mathrm{~h}$ (Nadubuya et al., 2010) and were milled a $2 \mathrm{~mm}$ sieve for chemical analysis (Retch ZM200, Haan, Germany). Four homogenous test samples were prepared from the fermented mushroom stalk (Fermented MS), unfermented mushroom stalk (MS), fermented mushroom cap (Fermented MC), and unfermented mushroom cap (MC); each was independently analyzed in triplicates, providing a total of 12 independent measurements of all treatments.

\section{Aspergillus niger}

Aspergillus niger (ATCC 9142) was obtained from the American Type Culture Collection (ATCC, USA). A. niger cultures were incubated at $24^{\circ} \mathrm{C}$ for 7 days in potato dextrose agar (PDA, MERCK) medium according to agar plate technique. After incubation, A. niger spores were harvested by inverting and tapping the top of the plate, slightly. Spores count was determined by Fuch-Rosenthal technique with hematocytometer. The spores were inoculated into the solid fermentation medium on the same day.

\section{Solid-State Fermentation}

After mushrooms and nutritional salt were autoclaved at $121^{\circ} \mathrm{C}$ for 15 minutes, one hundred $g$ mushroom stalk or cap and $160 \mathrm{ml}$ potato dextrose broth (Merck, Germany) was mixed in anaerobic bags. The $\mathrm{pH}$ during fermentation was calibrated to 5 using $1 \mathrm{~N} \mathrm{NaOH}$ and HCI. Starting humidity was $60 \%$ and for each $g$ of the solid environment $1 \times 10^{6}$ A. niger spores were inoculated into a sterile chamber and left to incubate at $28-30^{\circ} \mathrm{C}$. After incubation, fermented mushroom stalk or cap were placed in plastic containers, gently pressed, and left for 48 hours at ambient temperature. Since A. niger is a micro aerobic organism, there were sufficient micro aerobic conditions for its growth and development in this closed environment (David et al., 2003). After 48 hours, samples were spread over polyethylene paper and left for 6 days at $30-40^{\circ} \mathrm{C}$ until reaching approximately $90 \%$ of dry matter, after which they were splintered into $0.15-\mathrm{mm}$ pieces.

\section{Nutrient Composition of A. bisporus}

Crude ash content was determined by incineration in a muffle furnace at $550^{\circ} \mathrm{C}$ for 8 hours. Nitrogen $(\mathrm{N})$ contents were analyzed using the Kjeldahl method according to the AOAC (1998) procedure. Crude protein (CP) was calculated as $N \times 6.25$. The ether extracts $(\mathrm{EE})$ content was determined by using AnkomXT15 analyzer (AOAC, 1998). Crude fiber content was determined by using The ANKOM $^{2000}$ Fiber Analyzer. The analyses of neutral detergent fiber (NDF), acid detergent lignin (ADL), and acid detergent fiber (ADF) contents of the leaves were based on the method of Van Soest et al. (1991) using an Ankom fiber analyzer. Hemicellulose was calculated as NDF minus ADF. Nitrogen-free extract (NFE) was estimated on a dry weight basis by subtracting the percentages of CP, EE, CF and CA from $100 \%$.

\section{Statistical Analysis}

The data were analyzed by using Windows version of SPSS 21.0 (SPSS Inc., NY, and USA) statistical package program. T-test was used to compare the differences between groups after Shapiro-Wilk test was used for the normality assumption of data.

\section{Results and Discussion}

The nutrient composition of MS and fermented MS before and after fermentation was presented in Table 1. According to the data, the $\mathrm{CF}(\mathrm{P}<0.01), \mathrm{CP}, \mathrm{CA}, \mathrm{NDF}$ and $\mathrm{ADF}$ of the fermented MS were higher than those of MS $(\mathrm{P}<0.001)$. There were no differences between treatments in terms of $\mathrm{EE}$ and $\mathrm{ADL}(\mathrm{P}>0.05)$. The variation in nutrient composition of MC or the fermented MC was generally similar to those of MS or the fermented MC (Table 2). While the CP, CA, CF, ADF, and ADL of fermented MC were increased, its NFE and hemicellulose were decreased $(\mathrm{P}<0.05)$. The EE and NDF contents of both $\mathrm{MC}$ and fermented $\mathrm{MC}$ were not found differences. In general, these findings have been consistent with studies reported that fermented feed raw materials, agricultural wastes, and agricultural by-products were better nutrient composition according to non-fermented products (Mathivanan et al., 2006; Zhang et al., 2012; Zhao et al., 2013). On the other hand, the finding regarding the increase in cellulose content of MS after fermentation has been contradicted with the findings of many studies indicating that cellulose content decreases after fermentation (Iluyemi et al., 2006; Zhang et al., 2007; Lawal et al., 2010; Güngör et al., 2017; Altop et al., 2018; Jannathulla et al., 2018). These incompatibilities among the studies may be due to the chemical properties (cellulose content) of the substrates used, the type of microorganisms selected (fungi, bacteria, yeast, etc.), fermentation ambient conditions (humidity, temperature, $\mathrm{O}_{2}$ ) or variability in fermentation times.

In this study, an increase in protein content of fermented MS was an expected finding. Indeed, the protein content of the fermented product was higher than those of non-fermented products in previous studies (Zhang et al., 2007; Güngör et al., 2017; Jannathulla et al., 2018; Altop 
et al., 2018). This was associated with an increased amount of fungus or bacteria during fermentation process (Raimbault, 1998; Nair et al., 2008). Bacteria or fungi selected for fermentation have been also microbial protein sources and their protein contents were high. Therefore, the increase in protein content of fermented MC could be explained with the increased amount of $A$. niger during the fermentation process in the present study. On the other hands, the cellulose content of fermented MS was increased, contrary to other studies (Iluyemi et al., 2006; Zhang et al., 2007; Lawal et al., 2010; Güngör et al., 2017; Altop et al., 2018; Jannathulla et al., 2018 ). This could be closely related to the increased amount of A. niger in the fermentation process like the increase in protein content. In A. niger cell, its cell wall usually have exhibited a multilaminar and fibrillar feature, and this could increase the stability of the cell wall. Aspergillus niger has contained polysaccharides (about $80 \%$ ), protein $(5-15 \%)$ and lipids (3-10\%). Among the polysaccharides, glucan, galactose, chitin, chitosan, mannan, and cellulose are the most abundant (Arda, 2000). Considering the changes in the $\mathrm{EE}$ and $\mathrm{CP}$ content of the fermented MS in the study, it could be said that the increase in $\mathrm{CF}$ content was due to the increase in $A$. niger number during fermentation process.

Table 1 Changes in nutrient composition of Agaricus bisporus mushroom stalk before and after fermentation (based on DM \%)

\begin{tabular}{|c|c|c|c|c|}
\hline Composition, $\%$ & MS & Fermented MS & SEM & $\mathrm{P}$ \\
\hline $\mathrm{CP}$ & 22.36 & 30.40 & 1.798 & $* * *$ \\
\hline $\mathrm{EE}$ & 0.87 & 1.17 & 0.167 & NS \\
\hline $\mathrm{CA}$ & 11.42 & 14.74 & 0.749 & $* * *$ \\
\hline NFE & 51.42 & 29.22 & 4.979 & $* * *$ \\
\hline $\mathrm{CF}$ & 13.93 & 24.47 & 2.392 & $* * *$ \\
\hline NDF & 41.06 & 44.96 & 0.902 & $* *$ \\
\hline $\mathrm{ADF}$ & 19.49 & 28.54 & 2.029 & $* * *$ \\
\hline ADL & 6.42 & 6.59 & 0.493 & NS \\
\hline Hemicellulose & 21.57 & 16.43 & 1.153 & $* * *$ \\
\hline
\end{tabular}

**: $\mathrm{P}<0.01 ; * * *: \mathrm{P}<0.001$; NS: Not significant, NFE: nitrogen-free extract, SEM: standard error of means

Table 2 Changes in nutrient composition of Agaricus bisporus mushroom cap before and after fermentation (based on DM \%)

\begin{tabular}{|c|c|c|c|c|}
\hline Composition & $\mathrm{MC}$ & Fermented MC & SEM & $\mathrm{P}$ \\
\hline $\mathrm{CP}$ & 33.19 & 37.15 & 0.904 & $* * *$ \\
\hline $\mathrm{EE}$ & 1.62 & 1.30 & 0.201 & NS \\
\hline $\mathrm{CA}$ & 11.10 & 13.54 & 0.553 & $* * *$ \\
\hline NFE & 36.37 & 25.06 & 2.539 & $* * *$ \\
\hline $\mathrm{CF}$ & 17.72 & 22.94 & 1.178 & $* * *$ \\
\hline NDF & 51.87 & 40.66 & 3.741 & NS \\
\hline $\mathrm{ADF}$ & 19.76 & 28.08 & 1.867 & $* * *$ \\
\hline ADL & 5.51 & 8.69 & 0.730 & $* * *$ \\
\hline Hemicellulose & 32.11 & 12.58 & 5.130 & $*$ \\
\hline
\end{tabular}

*: $\mathrm{P}<0.05$; ***: $\mathrm{P}<0.001$; NS: Not significant, NFE: nitrogen-free extract, SEM: standard error of means

In the present study, the amount of CA of the fermented $\mathrm{MC}$ and MS were increased. These results are consistent within previous studies related to fermentation (Güngör et al., 2017; Altop et al., 2018). The increase in CA could be attributed to the phytase enzyme produced by the fermenter during the process (Selle et al., 2007; Adeola, 2010). In order to confirm this idea, it is important to determine the phosphorus content of the samples after fermentation. Therefore, more detailed studies are required. However, the presence of soil dust, etc. over the sample may affect its ash content. In the study, the higher CA content of the fermented MS as compared to MS could be attributed to the fact that the compost on the mushroom stalk could not be completely cleaned. On the other hands, the increase in CA content both of the fermented MS and MC confirmed the idea that content could be as a result of the growth and multiplication of the microorganism in the fermentation medium (Ahaotu et al., 2013)

The EE content of both the fermented MS and MC was not affected. This finding is disagree with the previous studies reported that the EE content of the product after fermentation increased or decreased (Ahmed et al., 2016; Güngör et al., 2017; Altop et al., 2018). Oboh et al (2002) suggested that the increase in the EE content might due to the increase in the microbial mass, activities of the lipolytic microorganism to secrete an extracellular enzyme (lipase), secretion of microbial oil into the fermenting medium and other products from metabolism. On the contrary, Vries and Visser (2001) suggested that the decreases in EE contents may be attributed to the degradation by extracellular enzymes secreted by $A$. niger; this strain secretes a number of enzymes including alphagalactosidase, hemicellulase, and pectinase. During fermentation, the enzymes secreted are known to metabolize carbohydrate as a carbon source for the growth of the strain (Nigam and Singh, 1994). Thus, it could be attributed that there was no differences between EE contents of fermented MC and MS because the fermenters used in this study had low lipase enzyme production potential or absence of lipolytic microorganism.

\section{Conclusion}

According to the results, it is possible to say that (1) both $A$. bisporus stalk and cap are suitable substrates for solid-state fermentation process, (2) the fermented mushroom products could be higher nutritive values than those of non-fermented. Thus, A. bisporus stalk (especially fermented stalk), is by product in mushroom production, has a potential nutritional value that can be considered as a protein source in farm animal nutrition. 


\section{References}

Adeola O. 2010. Phosphorus equivalency value of an Escherichia coli phytase in the diets of White Pekin ducks. Poultry Science, 89: 1199-1206.

Ahaotu I, Ogueke CC, Owuamanam CI, Ahaotu NN, Nwosu J.N. 2013. Fermentation of under watered cassava pulp by linamarase producing microorganisms: effect on nutritional composition and residual cyanide. American Journal of Food Nutrition, 3: 1-8.

Ahmed ST, Mun HS, Islam M, Ko SY, Yang C.J. 2016. Effects of dietary natural and fermented herb combination on growth performance, carcass traits and meat quality in growerfinisher pigs. Meat Science 122: 7-15.

AOAC. 1998. Officinal Methods of Analysis. 16th Edition, AOAC International, Gaithersburg, MD.

Altop A, Güngör E, Erener G. 2018. Aspergillus niger may improve nutritional quality of grape seed and its usability in animal nutrition through solid-state fermentation. International Advanced Researches and Engineering Journal, 2:273-7.

Arda M. 2000. Temel Mikrobiyoloji. Ankara Üniversitesi Veteriner Fakültesi, http://www.mikrobiyoloji.org /TR/Genel/BelgeGoster.aspx?F6E10F8892433CFFA79D6F 5E6C1B43FF380B7B4044EFB0A3\#_ftnref1

Buwjoom T, Tangtaweewipat S, Thongwittaya N, Yamauchi K. 2004. Chemical composition, nutrient digestibility and metabolizable energy of shiitake mushroom stalk meal. Journal of Poultry Science, 41:322-328.

Chu GM, Yang JM, Kim HY, Kim CH, Song YM. 2012. Effects of fermented mushroom (Flammulina velutipes) by-product diets on growth performance and carcass traits in growingfattening Berkshire pigs. Animal Science Journal, 83: 55-62.

Giannenas I, Pappas I, Mavridis S, Kontopidis G, Skoufos J, Kyriazakis I. 2010a. Performance and antioxidant status of broiler chickens supplemented with dried mushrooms (Agaricus bisporus) in their diet. Poultry Science, 89:303-311.

Giannenas I, Tontis D, Tsalie E, Chronis E, Doukas D, Kyriazakis I. 2010b. Influence of dietary mushroom Agaricus bisporus on intestinal morphology and microflora composition in broiler chickens. Research Veterinary Science, 89:78-84.

Guo F, Kwakkel R, Williams B, Li W, Li H, Luo J, Li X, Wei Y, Yan Z, Verstegen M. 2004a. Effects of mushroom and herb polysaccharides, as alternatives for an antibiotic, on growth performance of broilers. British Poultry Science, 45:684-694.

Guo F, Williams B, Kwakkel R, Li H, Li X, Luo J, Li W, Verstegen M. 2004b. Effects of mushroom and herb polysaccharides, as alternatives for an antibiotic, on the cecal microbial ecosystem in broiler chickens. Poultry Science, 83:175-182.

Güngör E, Altop A, Öztürk E, Erener G. 2017. Nutritional changes of sour cherry (Prunus cerasus) kernel subjected to Aspergillus niger solid-state fermentation. Journal of Tekirdag Agricultural Faculty, 99-103.

David H, Akesson M, Nielsen J. 2003. Reconstruction of the central carbon metabolism of Aspergillus niger. European Journal of Biochemistry, 270:4243-4253.

Iluyemi F, Hanafi M, Radziah O, Kamarudin M. 2006. Fungal solid state culture of palm kernel cake. Bioresource Technology, 97:477-82.

Jannathulla R, Dayal JS, Ambasankar K, Muralidhar M. 2018. Effect of Aspergillus niger fermented soybean meal and sunflower oil cake on growth, carcass composition and haemolymph indices in Penaeus vannamei Boone, 1931. Aquaculture, 486:1-8.

Kobayashi H, Iwami M, Ohgi K, Irie M. 1992. Primary structure of the non-specific and adenylic acid preferential ribonuclease from the fruit bodies of Lentinus edodes. Bioscience, Biotechnology and Biochemistry, 55: 2003-2010.
Lam SK, Ng TB. 2001. Hypsin, a novel thermostable ribosome inactivating protein with antifungal and antiproliferative activities from fruiting bodies of the edible mushroom Hypsizigus marmoreus. Biochemical and Biophysical Research Communications, 285:1071-1075.

Lawal T, Iyayi E, Adeniyi B, Adaramoye O. 2010. Biodegradation of palm kernel cake with multienzyme complexes from fungi and its feeding value for broilers. International Journal of Poultry Science, 9:695-701.

Lee S, Kwak W, Kim W. 2005. Studies on the selenium type and metabolism of selenium accumulation in the seleniumenriched mushroom, Flammulina velutipes, and its spent mushroom composts. Journal of Animal Science and Technology, 47:305-316.

Mathivanan R, Selvaraj P, Nanjappan K. 2006. Feeding of fermented soybean meal on broiler performance. International Journal of Poultry Science, 5:868-72.

Nadubuya A, Muyonga JH, Kabasa JD. 2010. Nutritional and hypocholesterolimic properties of Termitomyces microcarpus mushroom. African Journal of Food, Agriculture, Nutrition and Development, 10:3.

Nair SC, Sindhu R, Shashidhar S. 2008 Fungal xylanase production under solid state fermentation and submerged fermentation conditions. African Journal of Microbiology Research, 2:82-86.

Nigam P, Singh D. 1994. Solid-state (substrate) fermentation systems and their applications in biotechnology. Journal of Basic Microbiology, 34:405-423.

Oboh G, Akindahunsi AA, Oshodi AA. 2002. Nutrient and antinutrient content of Aspergillus niger fermented cassava products (flour and gari). Journal of Food Composition and Analysis, 15:617-622.

Raimbault MJ. 1998. General and microbiological aspects of solid substrate fermentation. Electronic Journal of Biotechnology, 1:395-99.

Selle PH, Ravindran V. 2007. Microbial phytase in poultry nutrition. Animal Feed Science and Technology. 135:1-41.

TUIK. 2016. Türkiye İstatistik Kurumu. www.tuik.gov.tr.

Van Soest PV, Robertson JB, Lewis BA.1991. Methods for dietary fiber, neutral detergent fiber, and nonstarch polysaccharides in relation to animal nutrition. Journal of Dairy Science, 74:3583-3597.

Vries RP, Visser J. 2001. Aspergillus enzymes involved in degradation of plant cell wall polysaccharides. Microbiology and Molecular Biology Reviews, 65:497-522.

Wang HX, Ng TB. 1999. Natural products with hypoglycemic, hypotensive, hypocholesterolemic, antiatherosclerotic and antithrombotic activities. Life Science, 65:2663-2277.

Wang HX, Ng TB, Liu QH. 2002. Isolation of a new heterodimeric lectin with mitogenic activity from fruiting bodies of the mushroom Agrocybe cyilndracea. Life Science,70:877-886.

Wong KH, Cheung PCK, Wu JZ. 2003. Biochemical and microstructural characteristics of insoluble and soluble dietary fiber prepared from mushroom sclerotia of Pleurotus tube-regium, Polyporus rhinoceros, and Wolfiporia cocos. Journal of Agricultural and Food Chemistry 51: 7197-7202.

Zhang X, Cao F, Sun Z. 2012. Effect of feeding Aspergillus nigerfermented Ginkgo biloba-leaves on growth, small intestinal structure and function of broiler chicks. Livestock Science, 147:170-80.

Zhang W-J, Xu Z-R, Zhao S-H, Sun J-Y, Yang X. 2007. Development of a microbial fermentation process for detoxification of gossypol in cottonseed meal. Animal Feed Science and Technology, 135:176-86.

Zhao L, Zhang X, Cao F, Sun D, Wang T, Wang G. 2013. Effect of dietary supplementation with fermented Ginkgo-leaves on performance, egg quality, lipid metabolism and egg-yolk fatty acids composition in laying hens. Livestock Science, 155(1):77-85. 